\title{
Vocabulary Learning Strategies of Iranian upper-intermediate
}

\section{EFL learners}

\author{
Mohammad Khatib \\ Assistant Professor of Applied Linguistics, Allameh Tabataba'i University, Tehran, Iran \\ E-mail: mkhatib27@yahoo.com
}

Mohammad Hassanzadeh

Faculty Member of Vali-e-Asr University, Rafsanjan, Iran

E-mail: vatan206@yahoo.com

Saeed Rezaei (Corresponding Author)

Department of English Language and Literature, Allameh Tabataba'i University, Tehran, Iran

\& Department of Languages and Linguistics, Sharif University of Technology, Tehran, Iran

E-mail: srezaei@sharif.edu

Received: February 11, 2011 Accepted: February 28, 2011 doi:10.5539/ies.v4n2p144

\begin{abstract}
This study examines the preferred vocabulary learning strategies of Iranian upper-intermediate EFL learners. In order to identify the aforementioned group in terms of language proficiency, a TOEFL test was administered to a population of 146 undergraduate EFL students at the university of Vali-e-Asr in Rafsanjan, Iran. Those scoring above 480 were arbitrarily labeled as upper-intermediate. Subsequently a questionnaire known as VOLSI (Vocabulary Learning Strategies Inventory) was given to the same subjects to come up with their preferred vocabulary learning strategies. Finally, a stepwise multiple regression analysis revealed that $11.4 \%$ of the variance in the learners' L2 proficiency can be accounted for by three strategy categories involving self-motivation, word organization, and authentic language use .In addition, an independent-samples t-test indicated no significant difference between learners' gender and their VLS choice.
\end{abstract}

Keywords: Vocabulary Learning Strategies (VLS), Vocabulary Learning Strategies Inventory (VOLSI), Strategy Inventory for Language Learning (SILL)

\section{Introduction}

Owing to the challenging demands of a highly competitive world, many foreign/second language learners are in desperate search for time-efficient strategies to cope with the never-ending lexical predicaments inter alia, inherent in any language.

At any rate, resourceful learners often try and develop short cuts for effective vocabulary learning in the face of existing time constraints. Vocabulary Learning Strategies (VLS) research attempts to explore and introduce such coveted short cuts and to this end, draws on the initiatives taken by successful learners in order to provide a useful roadmap for those in need. The increasing body of research on VLS, particularly in the last two decades as Atay and Ozbulgan (2007) also maintain, wishes to shed more light on learners' strategy repertoire and facilitate second/foreign language vocabulary learning and recall. All in all, research shows that many learners employ learning strategies in vocabulary learning more frequently than in any other language learning activities (O'Malley, Chamot, Stewner-Manzanares, Kupper, \& Russp, 1985).

Studies on VLS have been conducted from various perspectives and in relation to various factors to date. In their seminal article, Oxford and Scarcella (1994) highlighted guessing from context as the most useful strategy by far and advised teachers to teach vocabulary through as many fully contextualized activities as possible. Lawson and Hogben (1996) also emphasized the role of context in vocabulary acquisition, making a distinction between the use of context for generation of meaning of a new word and for acquisition of the meaning for subsequent recall. The 
role of vocabulary learning from context has also been pinpointed by Nassaji (2003), who concluded that success was related to the quality rather than quantity of the strategies used.

The use of mnemonic techniques has also been one of the most popular topics with regard to VLS, centering mainly on the efficacy of the keyword method (Atkinson, 1975; Gu, 2003; Rodriguez, 1999; Sagarra \& Alba, 2006; Shapiro \& Waters, 2005; Thompson, 1987).

On the other hand, one of the fastest growing areas with respect to VLS has been the studies on Computer Assisted Vocabulary Learning (CAVL) which indicates that learners can successfully learn words using specialized programs available on CD-ROMs, the Internet, and popular computer games. One major advantage of CAVL is that learners can control and direct their own learning (Pavičić, 2008). Among the existing works, Segler, Pain and Sorace's (2002) paper on the role of VLS in ICALL environments is worthy of attention.

\subsection{VLS Taxonomy and Psychometric Tools}

Researchers in the area of second/foreign language teaching have classified vocabulary learning strategies differently, the most prominent of which are the ones developed by Gu and Johnson (1996), Schmitt (1997), Hatch and Brown (2000), and Nation (2001). Classification of VLS as Nyikos and Fan (2007) pointed out, has achieved only mild consensus to date. Ahmed (1989, cited in Nyikos \& Fan, 2007) grouped the 38 strategies his Sudanese learners used into five macro strategies of memorization, practice, dictionary use, note-taking, and groupwork. Gu and Johnson (1996) developed a 91-item VLS questionnaire dividing it into sections including metacognitive regulation, guessing strategies, dictionary strategies, memory strategies ( rehearsal and encoding), and finally activation strategies. Their study underscored the fact that learners use a combination of strategies rather than single individual ones in learning vocabulary. Using cluster analysis, they classified learners by their strategy profiles and learning outcomes.

Drawing on the more general Strategy Inventory for Language Learning (SILL) designed by Oxford (1990), Schmitt (1997) developed a 58-item questionnaire including the previous four categories (social, cognitive, metacognitive, and memory strategies), complemented by a new category entitled 'determination' strategies under his overarching distinction between discovery strategies (strategies for learning what an unknown word means) and consolidation strategies (strategies for both learning word meaning and integrating it into the vocabulary). However, Hatch and Brown (2000) divided VLS into five integral steps, namely:

(1) Encountering new words;

(2) creating a mental picture;

(3) learning the words meaning;

(4) creating a strong linkage between word form and meaning in the memory; and

(5) using words

Nation (2001) offers his own taxonomy categorizing the types of strategies under three umbrella phases of: 1) Planning 2) Sources and 3) Processes.

One of the most in-depth studies of VLS, however, belongs to Stoffer (1995) who designed a questionnaire (VOLSI) consisting of 53 likert-type individual strategies, and then had them factor analyzed into the following nine categories:

(1) strategies involving authentic language use

(2) strategies involving creative activities

(3) strategies used for self motivation

(4) strategies used to create mental linkages

(5) memories strategies

(6) visual/auditory strategies

(7) strategies involving physical action

(8) strategies used to overcome anxiety and

(9) strategies used to organize words

This measurement scale (VOLSI) gives information about the behavior of foreign language learners. It is possible to find out how frequently students use VLS and what kind of strategies they use. The evidence of construct -related, 
content -related and criterion-related validity was provided respectively using factor analysis, consultation with experts and correlating with Oxford's SILL. Furthermore, a correlation study using Cronbach alpha was used to obtain the reliability of the VOLSI $\left(\mathrm{r}_{\mathrm{xx}}=.86\right)$. The most frequent strategy used in Stoffer's study was item 5 (link to L1 words similar in spelling) and overall, the fourth group of strategies (strategies for creating mental linkages). It was also found that learners who had previously received some kind of VLS instructions used these strategies more frequently than those with no instructions whatsoever. The age of the language learners appeared to be significant on seven of the nine factors. Gender differences, however failed to be significant only by a small margin.

The majority of studies in question imply that learners possess some sort of VLS inventory, though they do not make a systematic use of it and therefore are in need of instruction. For example, learners know surprisingly little about the use of mnemonics that can help them to integrate new material in the existing cognitive units (Thompson, 1987).

\subsection{VLS in Relation to Other Factors}

The use of VLS in association with field sensitivity was investigated by Chiang (2004) who also observed that older students were inclined to employ more strategies in vocabulary learning. The Taiwanese students in his research who pursued English major reported being more positive towards the use of almost all VLS than their non-English peers. Yu (2000) also examined the use of VLS from sociocultural perspectives through a comparative study of Japanese, Korean and Taiwanese EFL learners. The study showed that mediating agents, especially teachers' attitude and teaching methods have a great influence on learners' beliefs and strategy use.

\subsection{VLS and Gender}

Choice of VLS and gender differences has also been at the core of some researches. Experimental evidence in Nyikos (1987) indicated that men outperformed women significantly with regard to visual and color association strategy for vocabulary learning. However, a close analysis of data in Catalan's study (2003) indicated females' greater use of formal rule strategies, input elicitation strategies, rehearsal strategies and planning strategies, and males' greater use of image vocabulary learning strategies. In addition, the females' total strategy usage percentages were higher than the males', which points to either different perceptions of vocabulary learning behaviors or different patterns of vocabulary strategy usage for males and females.

\section{Objectives of the Study and Research Questions}

Considering all the above-mentioned studies and their implications and significance, this study attempts to unravel which vocabulary learning strategies are used by Iranian EFL learners at the upper-intermediate level. Also this study tries to investigate if there is any relationship between gender and language learners' use of vocabulary strategies in vocabulary learning.

In brief, drawing on the nine categories (factor structures) of VLS introduced by Stoffer (1995)- discussed earlier-this paper seeks to explore the following research questions:

1) Which category (or categories) of Stoffer's VLS are used by upper-intermediate learners?

2) Is there a significant relationship between the Iranian upper-intermediate EFL learners' gender and their use of (Stoffer's) VLS?

\section{Method}

\subsection{Subjects}

The sample pool consisted of 146 undergraduate students all majoring in English language at Vali-e-Asr University of Rafsanjan, Iran. The students were intact groups ranging from the first to seventh semester (113 female and 33 male). Following the administration of a TOEFL (paper-based) test, participants scoring above 480 were classified as upper-intermediate. In effect, the participants' L2 proficiency was operationally defined as their score in the TOEFL test.

\subsection{Instruments}

Addressing the preceding research questions, a Vocabulary Learning Strategies Questionnaire (VOLSI) which had been previously administered and validated (Stoffer, 1995) was utilized in this study as a tool to elicit the vocabulary learning strategies used by Iranian language learners. VOLSI is a 53-item likert scale from 1(never) to 5(always). Also a TOEFL test was used at the outset of the study in order to measure the participants' language proficiency. 


\subsection{Procedure}

In this study, respondents were asked to indicate how frequently they used the strategies in the questionnaire for vocabulary learning. Since all the participants were English majors, VOLSI was not translated into the learners' mother tongue (i.e., Farsi). Meanwhile, in order to exercise caution, some problematic words that might have presumably blocked comprehension (e.g. collage) were further defined before distributing the inventory. Filling the questionnaire on average took about 15 to 20 minutes.

In summary, to recognize the respondents' L2 proficiency level, a paper-based TOEFL test was given to them a few days following the distribution of VOLSI. The major reason for the TOEFL test was to distinguish the more proficient learners later titled as upper-intermediate (those scoring above 480). Secondly, a panel of instructors at Vali-e-Asr University was also consulted to judge on the subjects' proficiency level who interestingly corroborated the L2 proficiency level of this group categorized as upper-intermediate.

\subsection{Data Analysis and Results}

Table 1 below illustrates the overall 146 participants' mean scores on the TOEFL test as well as the nine strategy types most frequently used by them in vocabulary learning.

In order to find out more about the strategies espoused by more proficient students, a stepwise multiple regression analysis was conducted yielding the following coefficients.

As can be seen from the above tables, a stepwise multiple regression analysis was used in order to identify the vocabulary learning strategies that are the best predictors of L2 proficiency. Table 2 indicates that St 2 (items ranked in factor 2) have obtained the highest mean score of all. Table 3 displays three categories of strategies (out of nine) that are significant predictors of the participants' total TOEFL score (see appendix A. for factor loadings of the three most popular strategy types among more proficient students), with factor 2 ranking first in the model (3.3\% of the variance). The second most effective predictor turned out to be factor 3 ( $4.1 \%$ of the variance) and eventually factor 1 as the third predictor ( $4.0 \%$ of the variance).

Therefore, it can be concluded that $11.4 \%$ of the variance in L2 proficiency can be accounted for by the above-mentioned three strategy categories. Automatically, 6 out of 9 categories (or factors) did not significantly predict the subjects' overall L2 proficiency. The alpha level used for all tests of significance was .05 in this study.

Addressing the second research question, an independent samples t-test (see appendix B. for the table of results) was used to test the influence of gender on the learners' use of VLS. The results suggested that none of the strategy categories can be significantly $(\mathrm{p}<.05)$ related to the gender of the learners $\left(H_{0}\right.$ was not rejected). Therefore the two groups turn out to be equal in terms of VLS use.

\section{Conclusion}

The current paper provides a new dimension to an earlier study by Stoffer (1995) who investigated the underlying factor structures of Vocabulary Learning Strategies Inventory. She demonstrated through principal components factor analysis procedure that the 53 items of the VOLSI were clustered around nine dimensions related to the area of vocabulary learning. As an extension to this study, the researchers in this attempted to explore potential associations of the nine VLS factor structures with the strategies used by more proficient learners. In so doing, a TOEFL test was administered to 146 English majors to discriminate between higher level and lower level learners in terms of language proficiency. In a few days' time, a questionnaire (VOLSI) was given to all subjects to discover their vocabulary learning strategic priorities. Finally, a stepwise multiple regression analysis conducted to the scales revealed that only three out of nine factors panned out to be significant predictors of L2 proficiency. In effect, more proficient learners tended to make greater use of the above sets (see Table 2.) either through instruction or personal experience.

The strategy types identified with VLS choice of higher level learners could act as an eye-opener in terms of strategies of success for lower proficiency learners and those who seek out effective techniques likely to culminate in better retention of $\mathrm{L} 2$ vocabulary.

Language teachers ought to be on the lookout to permanently tap into learners' language awareness through strategy training or SBI (Strategy-Based Instruction) considering the fact that research provides support for learners to be successful.

\section{References}

Atay, D., \& Ozbulgan, C. (2007). Memory strategy instruction, contextual learning and ESP vocabulary recall. English for Specific Purposes, 26, 39-51 
Atkinson, R.C. (1975). Mnemotechnics in second language learning. American Psychologist, 30 (8), 821-28

Catalan, R. M. J. (2003). Sex differences in L2 vocabulary learning strategies. International Journal of Applied Linguistics. 13 (1), 54-77

Chiang, H. (2004). The relationship between field sensitivity/field independence and the use of vocabulary learning strategies of EFL university students in Taiwan. Unpublished doctoral dissertation, Texas A\&M University-Kingsville.

Gu, P.Y. (2003). Vocabulary learning in a second language: Person, task, context and strategies. TESL-EJ, 7(2).

Gu, P.Y., \& Johnson, R.K. (1996). Vocabulary learning strategies and language learning outcomes. Language Learning, 46, 643-679

Hatch, E. \&. Brown, C. (2000). Vocabulary, semantics, and language education (3 $3^{\text {rd }}$ ed.). Cambridge: Cambridge University Press.

Lawson, M.J. \& Hogben, D. (1996). The vocabulary learning strategies of foreign language students. Language Learning, 46, 101-135

Nassaji, H. (2003). L2 vocabulary learning through context: Strategies, knowledge sources, and their relationship with success in L2 lexical inferencing. TESOL Quarterly 37(4), 645-70

Nation, I.S.P. (2001). Learning vocabulary in another language. Cambridge: Cambridge University Press.

Nyikos, M. \& Fan, M. (2007). A review of vocabulary learning strategies: Focus on language proficiency and learner voice. In A. D. Cohen \& E. Macaro. (eds.), Language Learner Strategies (pp. 251-274). Oxford: Oxford University Press.

Nyikos, M. (1987). The effect of color and imagery as mnemonic strategies on learning and retention of lexical items in German. Unpublished doctoral dissertation, Purdue University, U.S.

O’Malley, J.M., Chamot, A.U., Stewner-Manzanares, G., Kupper, L. and Russo, R. (1985). Learning strategies used by beginning and intermediate ESL students. Language Learning, 35 (1), 21-64

Oxford, R. L. (1990). Language learning strategies: What every teacher should know. New York: Newbury House.

Oxford, R. \& Scarcella, R.C. (1994). Second language vocabulary learning among adults: State of the art in vocabulary instruction. System, 22 (2), 231-243

Pavičić, V. (2008). Vocabulary learning strategies and foreign language acquisition. Multilingual Matters Ltd; Crowell Press Ltd.

Rodriguez, M. (1999). Efficacy of rote, keyword, and context/keyword learning strategies on retention of vocabulary in EFL classrooms. Unpublished doctoral dissertation, University of Southern California.

Sagarra, N. \& Alba, M. (2006). The key is in the keyword: L2 vocabulary learning methods with beginning learners of Spanish. The Modern Language Journal, 90 (ii), 228-243

Schmitt, N. (1997). Vocabulary learning strategies. In N. Schmitt \& M. McCarthy (Eds.), Vocabulary: description, acquisition and pedagogy (pp.199-228). Cambridge: Cambridge University Press.

Segler, T. Pain, H. \& Sorace, A. (2002). Second language vocabulary acquisition and learning the strategies in ICALL environments. Computer Assisted Language Learning, 15(4), 409-14

Shapiro, A. M. \& Waters, D. L. (2005). An investigation of the cognitive processes underlying the keyword method of foreign vocabulary learning. Language Teaching Research 9 (2), 129-146

Stoffer, I. (1995). University foreign language students' choice of vocabulary learning strategies as related to individual difference variables. Unpublished doctoral dissertation, University of Alabama, USA.

Thompson, I. (1987). Memory in language learning. In A. Wenden \& J. Rubin (eds.), Learner Strategies in Language Learning (pp. 43-56). New York: Prentice Hall.

$\mathrm{Yu}, \mathrm{S} . \mathrm{T}$. (2000). Understanding the use of vocabulary learning strategies from socio-cultural perspectives. Unpublished doctoral dissertation, Southern Illinois University Carbondale. 
Table 1. Descriptive Statistics of the Participants' TOEFL Test Results

\begin{tabular}{|c|c|c|c|}
\hline & Mean & $\begin{array}{c}\text { Std. } \\
\text { Deviation }\end{array}$ & $\mathrm{N}$ \\
\hline TOEFL & 405.3630 & 50.81255 & 146 \\
\hline st1 & 2.5521 & .59645 & 146 \\
\hline st2 & 3.5130 & .56303 & 146 \\
\hline st3 & 2.4090 & .66407 & 146 \\
\hline st4 & 2.9007 & .46769 & 146 \\
\hline st5 & 3.3168 & .54933 & 146 \\
\hline st6 & 2.3233 & .62544 & 146 \\
\hline st7 & 2.5587 & .61712 & 146 \\
\hline st8 & 3.0098 & .57060 & 146 \\
\hline st9 & 3.2427 & .51532 & 146 \\
\hline
\end{tabular}

Table 2. Dependent Variable: Total Coefficients (a)

\begin{tabular}{|l|l|c|c|c|c|c|}
\hline \multirow{2}{*}{ Model } & & \multicolumn{2}{|c|}{$\begin{array}{c}\text { Unstandardized } \\
\text { Coefficients }\end{array}$} & $\begin{array}{c}\text { Standardized } \\
\text { Coefficients }\end{array}$ & $\mathrm{T}$ & Sig. \\
\cline { 3 - 7 } & & $\mathrm{B}$ & Std. Error & Beta & B & Std. Error \\
\hline \multirow{3}{*}{1} & (Constant) & 347.560 & 26.307 & & 13.212 & .000 \\
\cline { 2 - 7 } & st2* & 16.454 & 7.395 & .182 & 2.225 & .028 \\
\hline \multirow{3}{*}{3} & (Constant) & 363.250 & 26.585 & & 13.664 & .000 \\
\cline { 2 - 7 } & st2 & 23.291 & 7.758 & .258 & 3.002 & .003 \\
\cline { 2 - 7 } & st3 & -16.484 & 6.578 & -.215 & -2.506 & .013 \\
\cline { 2 - 7 } & (Constant) & 364.703 & 26.104 & & 13.971 & .000 \\
\cline { 2 - 7 } & st2 & 12.082 & 8.813 & .134 & 1.371 & .173 \\
\cline { 2 - 7 } & st3 & -27.920 & 7.885 & -.365 & -3.541 & .001 \\
\cline { 2 - 7 } & st1 & 25.656 & 10.150 & .301 & 2.528 & .013 \\
\hline
\end{tabular}

$*$ st $=$ strategy

Table 3.

\begin{tabular}{|c|c|c|c|c|c|c|c|c|c|}
\hline & & R & R & Adjusted \\
M Square & $\begin{array}{c}\text { Std. Error of } \\
\text { the Estimate }\end{array}$ & \multicolumn{5}{|c|}{ Change Statistics } \\
\hline 1 & $.182(\mathrm{a})$ & .033 & .027 & 50.13409 & .033 & 4.951 & 1 & 144 & .028 \\
\hline 2 & $.272(\mathrm{~b})$ & .074 & .061 & 49.23954 & .041 & 6.280 & 1 & 143 & .013 \\
\hline 3 & $.337(\mathrm{c})$ & .114 & .095 & 48.33720 & .040 & 6.389 & 1 & 142 & .013 \\
\hline
\end{tabular}

a Predictors: (Constant), st2

b Predictors: (Constant), st2, st3

c Predictors: (Constant), st2, st3, st1 
Table 4. Descriptive Statistics

\begin{tabular}{|c|c|c|c|c|c|}
\hline & Sex & $\mathrm{N}$ & Mean & $\begin{array}{c}\text { Std. } \\
\text { Deviation }\end{array}$ & $\begin{array}{c}\text { Std. Error } \\
\text { Mean }\end{array}$ \\
\hline st1 & Female & 113 & 2.5027 & .57172 & .05378 \\
\hline & Male & 33 & 2.7212 & .65563 & .11413 \\
\hline st2 & Female & 113 & 3.4841 & .55268 & .05199 \\
\hline & Male & 33 & 3.6121 & .59517 & .10361 \\
\hline st3 & Female & 113 & 2.3780 & .66320 & .06239 \\
\hline & Male & 33 & 2.5152 & .66618 & .11597 \\
\hline st4 & Female & 113 & 2.8838 & .48057 & .04521 \\
\hline & Male & 33 & 2.9583 & .42236 & .07352 \\
\hline st5 & Female & 113 & 3.3142 & .56203 & .05287 \\
\hline & Male & 33 & 3.3258 & .51153 & .08905 \\
\hline st6 & Female & 113 & 2.2770 & .63513 & .05975 \\
\hline & Male & 33 & 2.4818 & .57198 & .09957 \\
\hline st7 & Female & 113 & 2.5651 & .62602 & .05889 \\
\hline & Male & 33 & 2.5368 & .59444 & .10348 \\
\hline st8 & Female & 113 & 3.0076 & .59020 & .05552 \\
\hline & Male & 33 & 3.0173 & .50603 & .08809 \\
\hline st9 & Female & 113 & 3.2073 & .51010 & .04799 \\
\hline & Male & 33 & 3.3636 & .52257 & .09097 \\
\hline TOEFL & Female & 113 & 399.9735 & 46.47281 & 4.37179 \\
\hline & Male & 33 & 423.8182 & 60.71627 & 10.56935 \\
\hline & & & & & \\
\hline
\end{tabular}

Appendix A.

1. Strategies involving authentic language use:

- Read L2 newspapers and magazines

- Read L2 literature and poetry

- Watch L2 movies

- Practice in conversation with L2 speaker

- Make up conversations with L2 speaker

- Write letters using new words

- Relate new words to myself

- Draw pictures of new words

- Link words in list by creating a story

- Use brainstorming to recall words

2. Strategies used for self-motivation:

- Encourage myself when afraid of mistakes

- Try to relax when afraid of using new words

- Pay attention to speech

- Feel successful when learning new words 
- Picture myself using word in situation

- Enjoy learning new vocabulary

- Aware of incorrect use

- Break words into its parts

- Use brainstorming to recall word

- Make up a sentence with each new word

3. Strategies used to organize new words:

- Organize new words on word processor

- Use computer programs to practice words

- Use videos used for L2 learners

- Make collages with related words

- Link words in list by creating a story

- Practice word by using real objects 
Appendix B.

\begin{tabular}{|c|c|c|c|c|c|c|c|c|c|c|}
\hline \multirow[b]{3}{*}{ st1 } & \multirow[b]{3}{*}{$\begin{array}{l}\text { Equal variances } \\
\text { assumed }\end{array}$} & \multicolumn{2}{|c|}{$\begin{array}{l}\text { Levene's Test for } \\
\text { Equality } \\
\text { Variances }\end{array}$} & \multicolumn{7}{|c|}{ t-test for Equality of Means } \\
\hline & & \multirow{2}{*}{$\frac{F}{2.031}$} & \multirow{2}{*}{$\begin{array}{l}\text { Sig. } \\
.156\end{array}$} & \multirow{2}{*}{$\begin{array}{l}\mathrm{T} \\
-1.868\end{array}$} & \multirow{2}{*}{ Df } & \multirow{2}{*}{$\begin{array}{l}\begin{array}{l}\text { Sig. } \\
\text { (2-tailed) }\end{array} \\
.064\end{array}$} & \multirow{2}{*}{$\begin{array}{l}\begin{array}{l}\text { Mean } \\
\text { Difference }\end{array} \\
-.21856\end{array}$} & \multirow{2}{*}{\begin{tabular}{l}
$\begin{array}{l}\text { Std. } \quad \text { Error } \\
\text { Difference }\end{array}$ \\
\multicolumn{1}{c}{.11702}
\end{tabular}} & \multicolumn{2}{|c|}{$\begin{array}{l}95 \% \text { Confidence Interva } \\
\text { of the Difference }\end{array}$} \\
\hline & & & & & & & & & -.44986 & .01274 \\
\hline & $\begin{array}{l}\text { Equal variances } \\
\text { not assumed }\end{array}$ & & & -1.732 & 47.127 & .090 & -.21856 & .12617 & -.47236 & .03524 \\
\hline \multirow[t]{2}{*}{ st2 } & $\begin{array}{l}\text { Equal variances } \\
\text { assumed }\end{array}$ & .432 & .512 & -1.151 & 144 & .252 & -.12805 & .11128 & -.34801 & .09191 \\
\hline & $\begin{array}{l}\text { Equal variances } \\
\text { not assumed }\end{array}$ & & & -1.105 & 49.254 & .275 & -.12805 & .11592 & -.36097 & .10487 \\
\hline \multirow[t]{2}{*}{ st3 } & $\begin{array}{l}\text { Equal variances } \\
\text { assumed }\end{array}$ & 1.236 & .268 & -1.044 & 144 & .298 & -.13715 & .13136 & -.39679 & .12249 \\
\hline & $\begin{array}{l}\text { Equal variances } \\
\text { not assumed }\end{array}$ & & & -1.041 & 51.960 & .302 & -.13715 & .13168 & -.40140 & .12710 \\
\hline \multirow[t]{2}{*}{ st4 } & $\begin{array}{l}\text { Equal variances } \\
\text { assumed }\end{array}$ & .294 & .589 & -.804 & 144 & .423 & -.07448 & .09265 & -.25762 & .10866 \\
\hline & $\begin{array}{l}\text { Equal variances } \\
\text { not assumed }\end{array}$ & & & -.863 & 58.387 & .392 & -.07448 & .08631 & -.24723 & .09826 \\
\hline \multirow[t]{2}{*}{ st5 } & $\begin{array}{l}\text { Equal variances } \\
\text { assumed }\end{array}$ & .279 & .598 & -.106 & 144 & .915 & -.01160 & .10907 & -.22718 & .20398 \\
\hline & $\begin{array}{l}\text { Equal variances } \\
\text { not assumed }\end{array}$ & & & -.112 & 56.533 & .911 & -.01160 & .10356 & -.21901 & .19581 \\
\hline \multirow[t]{2}{*}{ st6 } & $\begin{array}{l}\text { Equal variances } \\
\text { assumed }\end{array}$ & .073 & .788 & -1.665 & 144 & .098 & -.20483 & .12301 & -.44796 & .03830 \\
\hline & $\begin{array}{l}\text { Equal variances } \\
\text { not assumed }\end{array}$ & & & -1.764 & 57.080 & .083 & -.20483 & .11612 & -.43735 & .02769 \\
\hline \multirow[t]{2}{*}{ st7 } & $\begin{array}{l}\text { Equal variances } \\
\text { assumed }\end{array}$ & .323 & .571 & .231 & 144 & .818 & .02831 & .12251 & -.21384 & .27046 \\
\hline & $\begin{array}{l}\text { Equal variances } \\
\text { not assumed }\end{array}$ & & & .238 & 54.454 & .813 & .02831 & .11906 & -.21035 & .26697 \\
\hline \multirow[t]{2}{*}{ st8 } & $\begin{array}{l}\text { Equal variances } \\
\text { assumed }\end{array}$ & .633 & .427 & -.086 & 144 & .932 & -.00973 & .11329 & -.23366 & .21420 \\
\hline & $\begin{array}{l}\text { Equal variances } \\
\text { not assumed }\end{array}$ & & & -.093 & 59.780 & .926 & -.00973 & .10413 & -.21803 & .19857 \\
\hline \multirow[t]{2}{*}{ st9 } & $\begin{array}{l}\text { Equal variances } \\
\text { assumed }\end{array}$ & .000 & .999 & -1.540 & 144 & .126 & -.15630 & .10149 & -.35690 & .04429 \\
\hline & $\begin{array}{l}\text { Equal variances } \\
\text { not assumed }\end{array}$ & & & -1.520 & 51.155 & .135 & -.15630 & .10285 & -.36276 & .05016 \\
\hline \multirow[t]{2}{*}{ Total } & $\begin{array}{l}\text { Equal variances } \\
\text { assumed }\end{array}$ & 5.256 & .023 & -2.411 & 144 & .017 & -23.84 & 9.89 & -43.396 & -4.293 \\
\hline & $\begin{array}{l}\text { Equal variances } \\
\text { not assumed }\end{array}$ & & & -2.085 & 43.522 & .043 & -23.844 & 11.437 & -46.903 & -.7861 \\
\hline
\end{tabular}

